\title{
PENGARUH BUDAYA ORGANISASI TERHADAP KINERJA PEGAWAI BANK BJB CABANG BANJARMASIN
}

\author{
Sayid Hasan \\ Bank BJB Cabang Banjarmasin \\ Komp. Mustika Graha Asri Blok L No. 1, Banjarbaru \\ e-mail: curse.love12@gmail.com
}

\begin{abstract}
Company performance measurement is very important. By measuring performance, management can determine the level of progress of the company and identify areas which should receive more attention. This research try to understand the influence of organizational culture to employee's performance. This research is done to BJB Bank Branch Banjarmasin using all it's employees as research population. Based on these results that the regression tested in this study are significant. In other words, the influence of organizational culture on performance is not coincident, but actually real or meaningful.
\end{abstract}

Keywords: human resources management, organizational culture, employee performance

Abstrak: Pengukuran kinerja suatu perusahaan merupakan hal yang sangat penting. Dengan melakukan pengukuran kinerja, manajemen dapat mengetahui tingkat kemajuan perusahaan dan sekaligus mengetahui bidang-bidang mana yang harus mendapat perhatian lebih banyak. Penelitian ini berusaha memahami pengaruh dari budaya organisasi terhadap kinerja pegawai. Penelitian dilakukan di Bank BJB Cabang Banjarmasin dengan populasi penelitian adalah seluruh karyawan di Bank BJB Cabang Banjarmasin. Berdasarkan hasil penelitian ini dapat disimpulkan bahwa regresi yang diuji dalam penelitian ini adalah signifikan atau dengan kata lain pengaruh budaya organisasi terhadap kinerja adalah bukan karena hal kebetulan semata, melainkan benar-benar nyata atau bermakna.

Kata Kunci: manajemen sumber daya manusia, budaya organisasi, kinerja pegawai

\section{Latar Belakang}

Organisasi merupakan kesatuan sosial yang dikoordinasikan secara sadar, dengan sebuah batasan yang relatif dapat diidentifikasi, bekerja secara terus menerus untuk mencapai tujuan. Secara eksplisit, definisi tersebut mengasumsikan kebutuhan untuk mengkoordinasikan pola interaksi manusianya. Pola interaksi sumber daya manusia (SDM) dalam organisasi harus seimbang dan selaras agar organisasi dapat tetap eksis.

SDM yang potensial apabila didayagunakan secara efektif dan efisien akan bermanfaat untuk menunjang gerak lajunya pembangunan nasional yang berkelanjutan. Melihat kondisi SDM yang ada saat ini mengharuskan berpikir secara seksama yaitu bagaimana dapat memanfaatkan secara optimal. Dari sisi lain, tentunya agar di masyarakat tersedia SDM yang handal memerlukan perencanaan dan pengembangan berkelanjutan secara maksimal dari masing-masing pihak yang berkepentingan. Kelemahan dalam penyediaan berbagai fasilitas pengembangan SDM dapat mengakibatkan munculnya hambatan dalam pelayanan masyarakat dan produktivitas masyarakat. Pada umumnya mengenai kemampuan SDM yang ada masih jauh dari yang kita harapkan.

Kinerja pegawai yang merupakan hasil olah pikir dan tenaga dari seorang pegawai terhadap pekerjaan yang dilakukannya, dapat berwujud, dilihat, dihitung jumlahnya, akan tetapi dalam banyak hal hasil olah pikiran 
dan tenaga tidak dapat dihitung dan dilihat, seperti ide-ide pemecahan suatu persoalan, inovasi baru suatu produk barang atau jasa, bisa juga merupakan penemuan atas prosedur kerja yang lebih efisien. Temuan hasil studi tentang kinerja pegawai dipengaruhi oleh kepuasan kerja, budaya organisasi/perusahaan, serta gaya kepemimpinan.

Perkembangan dan persaingan industri perbankan yang semakin ketat mengharuskan setiap bank untuk memiliki strategi yang tepat dalam mencapai keunggulan bersaing. Dalam hal ini PT Bank BJB Tbk Cabang Banjarmasin harus mampu mengembangkan perusahaannya. Salah satunya dengan cara memiliki strategi yang baik dan unggul melalui perancangan strategi. Untuk membuat sebuah perancangan strategi yang baik, diperlukan alat manajemen strategi yang mampu secara komprehensif melihat perspektif yang ada dalam suatu perusahaan.

\section{Kajian Literatur}

McShane dan Von Glinow (2008:460) mengatakan, bahwa budaya organisasi yang kuat memiliki potensi meningkatkan kinerja, dan sebaliknya bila budaya organisasinya lemah mengakibatkan kinerja menurun. Budaya organisasi memiliki tiga fungsi penting yaitu sebagai sistem pengawasan, perekat hubungan sosial, dan saling memahami.

Kepemimpinan berperan dalam memperkuat dan mengubah budaya organisasi, pertama, pendiri dan pemimpin menjadi teladan dalam menjaga budaya organisasi. Pengaruh pendiri dan pemimpin melalui keteladanannya akan memperkuat budaya organisasi. Kedua, sistem reward (pemberian penghargaan) disesuaikan dengan nilai-nilai budaya organisasi. Dengan demikian, setiap anggota organisasi mengetahui dengan jelas perilaku yang mendatangkan penghargaan. Ketiga, artifaknya sesuai atau sejalan dengan kemajuan budaya yang berlaku di masyarakat. Contohnya, dulu pengelola rumah sakit arogan, mereka beranggapan pasien membutuhkan rumah sakit. Pada masa sekarang ketika persaingan ketat, pandangan berubah yaitu rumah sakit membutuhkan pasien. Keempat, proses seleksi dan sosialisasi mengacu pada kebutuhan organisasi. Calon pekerja yang di- pilih adalah mereka yang memiliki nilai-nilai yang sejalan dengan budaya organisasi.

Masing-masing anggota organisasi memiliki dorongan yang berbeda-beda agar karyawan mau bekerja dengan baik. Yang dimaksud mau bekerja dengan baik di sini adalah bahwa dorongan merupakan kesediaannya untuk mengeluarkan tingkat upaya yang lebih tinggi ke arah tercapainya sasaran bahkan tujuan organisasi.

Menurut Simamora (2004:409), kinerja karyawan adalah tingkat terhadapnya para karyawan mencapai persyaratan pekerjaan. Ada beberapa unsur yang dapt kita lihat dari kinerja seorang karyawan sebagai berikut ini.

1. Seorang karyawan dapat dikelompokkan ke dalam tingkatan kinerja tertentu dengan melihat aspek-aspeknya, seperti: tingkat efektifitas, efisiensi, keamanan dan kepuasan pelanggan yang di layani.

2. Tingkat efektifitas dapat dilihat dari sejauh mana seorang karyawan dapat memanfaatkan sumber-sumber daya untuk melaksanakan tugas-tugas yang sudah direncanakan, serta cakupan sasaran yang bisa dilayani.

3. Unsur keamanan-kenyamanan dalam pelaksanaan pekerjaan, mengandung dua aspek, baik aspek keamanan kenyamanan bagi karyawan maupun bagi pihak yang dilayani. Dalam hal ini penilaian aspek keamanan-kenyamanan menunjuk pada keberadaan dan kepatuhan pada standar pelayanan maupun prosedur kerja.

Penilaian kinerja merupakan suatu proses organisasi dalam menilai unjuk kerja pegawainya. Tujuan dilakukan penilaian kinerja secara umum adalah untuk memberikan umpan balik kepada pegawai dalam upaya memperbaiki tampilan kerjanya dan upaya meningkatkan produktivitas organisasi dan secara khusus dilakukan dalam kaitannya dengan berbagai kebijaksanaan terhadap pegawai seperti untuk tujuan promosi, kenaikan gaji, pendidikan dan latihan. Hal ini bertujuan agar penilaian kinerja dapat menjadi landasan untuk penilaian sejauh mana kegiatan MSDM seperti, perekrutan, seleksi, penempatan, dan pelatihan dilakukan dengan baik, dan apa yang akan dilakukan kemudian se- 
perti dalam penggajian, perencanaan karier, dan lain-lain.

Penelitian terdahulu yang menjadi pondasi dari penelitian ini adalah sebagai berikut ini.

1. Alindra (2015), meneliti tentang pengaruh budaya organisasi terhadap kinerja karyawan Depok Sports Center Yogyakarta. Penelitian ini menggunakan penelitian kuantitatif dengan menggunakan metode survei memakai. Teknik pengambilan data menggunakan angket. Populasi dalam penelitian ini adalah seluruh karyawan Depok Sports Center. Pengambilan sampel menggunakan teknik sampling jenuh yaitu seluruh karyawan Depok Sports Center yang berjumlah 18 orang. Teknik analisis data menggunakan uji korelasi. Hasil penelitian ini menunjukkan bahwa budaya organisasi memiliki pengaruh positif dan signifikan terhadap kinerja karyawan. Seringkali budaya dalam suatu organisasi berkembang dengan kuat, sehingga dalam kondisi demikian, setiap anggota mengetahui dengan baik tujuan organisasi yang akan dicapainya.

2. Soedjono (2005) meneliti tentang pengaruh budaya organisasi terhadap kinerja organisasi dan kepuasan kerja karyawan pada Terminal Penumpang Umum di Surabaya. Penelitian ini menggunakan metode survey, sampel dan kuesioner sebagai alat pengumpulan data utama. Structural Equation Modelling (SEM) dipakai untuk menganalisa model dengan bantuan program AMOS 4.0. Hasil penelitian menunjukkan bahwa (1) ada pengaruh signifikan budaya organisasi terhadap kinerja organisasi, (2) ada pengaruh signifikan kinerja organisasi terhadap karyawan, (3) ada pengaruh signifikan budaya organisasi terhadap kepuasan pelanggan, dan (4) tidak ada pengaruh langsung dari budaya organisasi yang diarahkan pada kinerja organisasi terhadap kepuasan karyawan.

3. Dalimunthe (2009), meneliti tentang pengaruh budaya organisasi terhadap kinerja pegawai pada Dinas Informasi Komunikasi dan Pengolahan Data Elektronik Kota Medan. Metode yang digunakan didalam penelitian ini adalah metode deskriptif kuantitatif dengan menggunakan teknik ana- lisa data korelasi. Hasil penelitian menunjukkan bahwa terdapat hubungan yang cukup kuat antara budaya organisasi dengan kinerja pegawai.

\section{Metode Penelitian}

Penelitian dilakukan pada Bank BJB Cabang Banjarmasin. Populasi penelitian ini adalah seluruh karyawan di Bank BJB Cabang Banjarmasin. Mengingat jumlah karyawan yang tidak terlalu besar, maka teknik sampling yang digunakan pada penelitian ini adalah sensus, yaitu seluruh populasi dijadikan responden penelitian.

Variabel yang diteliti adalah budaya organisasi dan kinerja, dimana penelitian ini ingin membuktikan apakah budaya organisasi memiliki pengaruh yang signifikan terhadap kinerja karyawan di Bank BJB Cabang Banjarmasin, atau tidak.

Teknik pengumpulan data yaitu dengan kuisioner yang bertujuan untuk mengetahui pendapat responden mengenai kinerja pegawai Bank BJB cabang Banjarmasin. Dengan observasi ke objek yang menjadi pusat penelitian guna mendapatkan dan mengumpulkan data yang diperlukan di dalam dan penulisan penelitian ini. Penelitian ini dilakukan dengan memeriksa catatan-catatan atau arsip yang ada hubungannya dengan penelitian ini maupun wawancara secara langsung kepada para pegawai Bank BJB cabang Banjarmasin.

\section{Hasil Penelitian dan Pembahasan}

Berdasarkan hasil analisis menunjukkan bahwa ada pengaruh budaya organisasi terhadap kinerja pegawai Bank BJB cabang Banjarmasin. Suatu organisasi, baik itu pemerintahan maupun swasta, selalu digerakkan oleh sekelompok orang yang berperan aktif untuk mencapai tujuan yang ingin dicapai dari organisasi tersebut. Tujuan organisasi tentunya tidak akan tercapai jika anggota atau pegawainya tidak maksimal.

Menurut Robbins (2008:296) hampir tidak ada keraguan bahwa suatu budaya sangat mempengaruhi sikap karyawan. Seringkali budaya dalam suatu organisasi berkembang dengan kuat, sehingga dalam kondisi demikian, setiap anggota mengetahui dengan baik tujuan organisasi yang akan dicapainya. Untuk mencapai tujuan tersebut akhirnya buda- 
ya organisasi memiliki kekuatan untuk mempengaruhi kehidupan organisasi dan produktivitas kerja.

Siagian (1995:227) mendefinisikan kinerja sebagai suatu keseluruhan kemampuan seseorang untuk bekerja sedemikian rupa sehingga mencapai tujuan kerja secara optimal dan berbagai sasaran yang telah diciptakan dengan pengorbanan yang secara rasio lebih kecil dibandingkan dengan hasil yang dicapai. Menurut Pabundu (2010: 121) kinerja adalah hasi-hasil fungsi pekerjaan/kegiatan seseorang atau kelompok dalam suatu organisasi yang dipengaruhi oleh berbagai faktor untuk mencapai tujuan organisasi dalam periode waktu tertentu.

Budaya organisasi tidak akan menjadi efektif tanpa adanya hubungan yang baik antar karyawan. Untuk membangun budaya organisasi, semua pelaku organisasi harusnya memiliki perasaan membutuhkan dan melaksanakan pekerjaan dengan hati yang ikhlas. Dengan memiliki perasaan tersebut setiap karyawan akan bekerja dengan penuh tanggung jawab untuk mengerjakan apa yang sudah menjadi beban kerjanya, sehingga semua karyawan bisa terlibat aktif dalam mencapai tujuan dari organisasi.

\section{Kesimpulan}

Berdasarkan hasil penelitian ini dapat disimpulkan bahwa hasil $t_{\text {hitung }}$ budaya organisasi (X) adalah sebesar 8,696 dan nilai $t_{\text {tabel }}$ sebesar 2,014 karena nilai $t_{\text {hitung }}(8,696>$ $2,014)$ atau nilai probabilitas (X) jauh lebih kecil dari pada nilai $\alpha(5 \%)$ maka dapat disimpulkan bahwa H0 ditolak, artinya regresi yang diuji dalam penelitian ini adalah signifikan atau dengan kata lain pengaruh budaya organisasi terhadap kinerja adalah bukan karena hal kebetulan semata, melainkan benarbenar nyata atau bermakna. Dengan demikian, dapat disimpulkan budaya organisasi berpengaruh signifikan terhadap kinerja.

Saran yang dapat diberikan kepada Bank BJB cabang Banjarmasin adalah sebagai berikut ini.

1. Berdasarkan hasil kuesioner, pemimpin hendaknya tidak segan untuk memberikan contoh kinerja yang bagus, serta senantiasa memberikan motivasi kepada karyawan dalam mengerjakan suatu pekerjaan, de- ngan begitu karyawan akan merasa nyaman dalam bekerja dan menciptakan budaya organisasi yang bagus.

2. Untuk kemajuan perusahaan hendaknya karyawan berperan aktif dalam memberkan saran, ide atau gagasan yang membangun, dengan begitu akan meningkatkan produktivitas kerja karyawan dan perusahaan.

3. Karyawan hendaknya dapat meningkatkan kedisiplinan dalam bekerja guna meningkatkan produktivitas kerja dalam perusahaan.

4. Manajemen dalam perusahaan seharusnya mempunyai peraturan yang bisa menjadikan para karyawan untuk tidak enggan untuk bermalas-malasan, supaya tercipta tempat kerja yang kondusif.

5. Pemimpin hendaknya lebih dapat berpartisipasi aktif dalam setiap kegiatan atau pekerjaan kelompok, sehingga pemimpin dapat menjadi contoh bagi karyawan, menjadi motivator yang selalu dapat memberkan semangat dan arahan kepada para karyawan dalam setiap pekerjaan yang dilaksanakan secara berkelompok dengan tujuan menciptakan budaya organisasi yang bagus dalam perusahaan.

\section{DAFTAR PUSTAKA}

Alindra Aput Ivan, 2015, “Analisis Pengaruh Budaya Organisasi terhadap Kinerja Karyawan Depok Sports Center", Skripsi, Universitas Negeri Yogyakarta, Yogyakarta.

Asfar Halim Dalimunthe, 2009, "Pengaruh Budaya Organisasi terhadap Kinerja Pegawai pada Dinas Informasi Koтиnikasi dan Pengolahan Data Elektronik Kota Medan, Universitas Sumatera Utara, Medan.

McShane, Steven L. dan Mary Ann Von Glinow,. 2008, Organizational behavior, Edisi ke-4, McGraw-Hill, New York.

Pabundu Tika, 2010, Budaya Organisasi dan Peningkatan Kinerja Perusahaan, Bumi Aksara, Jakarta.

Robbins P.S., 2008, Organizational Behavior, Prentice Hall, Inc., New Jersey. 
242 Jurnal Ilmiah Ekonomi Bisnis, Vol 3, No 2, Juli 2017, hal 238 - 242

Siagian Sondang P., 1995, Manajemen Sumber Daya Manusia, Elex Media Komputindo, Jakarta.

Simamora Henry, 2004, Manajemen Sumber Daya Manusia, Edisi ke-3, : STIE YKPN, Yogyakarta.
Soedjono, 2005 "Pengaruh Budaya Organisasi terhadap Kinerja Organisasi dan Kepuasan Kerja Karyawan Pada Terminal Penumpang Umum di Surabaya, Jurnal Manajeman dan Kewirausahaan, Vol 7, No 1. 